Theatre Research in Canada

Recherches théâtrales au Canada

\title{
Introduction: Teaching / Editing
}

Kim Solga

Volume 39, Number 1, 2018

URI: https://id.erudit.org/iderudit/1055463ar

DOI: https://doi.org/10.7202/1055463ar

See table of contents

Publisher(s)

Graduate Centre for the Study of Drama, University of Toronto

ISSN

1196-1198 (print)

1913-9101 (digital)

Explore this journal

Cite this document

Solga, K. (2018). Introduction: Teaching / Editing. Theatre Research in Canada / Recherches théâtrales au Canada, 39(1). https://doi.org/10.7202/1055463ar

All Rights Reserved (C Theatre Research in Canada / Recherches théâtrales au Canada, 2018
This document is protected by copyright law. Use of the services of Érudit (including reproduction) is subject to its terms and conditions, which can be viewed online.

https://apropos.erudit.org/en/users/policy-on-use/
This article is disseminated and preserved by Érudit.

Érudit is a non-profit inter-university consortium of the Université de Montréal, Université Laval, and the Université du Québec à Montréal. Its mission is to promote and disseminate research.

https://www.erudit.org/en/ 


\section{Teaching / Editing}

KIM SOLGA

I had my first formative experience of editing long before I became an editor myself. It was the early 200os, and I had turned a particularly well-reviewed course paper on Mother Courage and Her Children into an article at the suggestion of one of my professors. Friends and mentors told me to aim high for a start, so off the paper went to Theatre fournal (revised, of course, but not actually edited-as I soon discovered). A few weeks later I got a lovely rejection letter from then-editor David Román. He wrote very kind things, but the upshot was crushing: he was not prepared to send this one out for peer review.

I was devastated. My paper had garnered such compliments on its theoretical strength and originality from my professor; how could Dr Román not see that? Or was it simply that, even at my best, I wasn't good enough? I cried for a bit, sent a needy note to my best friend (who was supportively angry on my behalf, bless him), and then, after a suitable period of mourning, I got in touch with Joanne Tompkins.

Joanne (along with Ric Knowles and Bill Worthen) were my supervisors (and joint editors) at Modern Drama, where I was an editorial assistant at the time. I was the citation checker-a much-overlooked but absolutely essential assistantship gig at any publishing venue. Thanks to that job (and to the generous support of Bill, Joanne, and Ric) I learned slowly but surely what a good article looks like when it first arrives in an editor's inbox, how it changes after it's been through rigorous editing, and - crucially-how full of small formatting and citation errors it inevitably will be, even by the end of the process. (My main takeaway from my job at $M D$ will always be: always check your own citations before you hit send!)

Thanks to Joanne's mentorship in particular, I knew I could turn to her in this, my time of publishing need. I asked if she'd read my paper (exactly as it had been rejected) and let me know her thoughts; she kindly agreed. What she explained to me after reading my failed submission was life-changing; not only have I never forgotten her advice, but I make a point of passing it on to all of my graduate students, as well as to any writer (young or not young) with whom I find myself in an editorial relationship.

First, Joanne told me, a course paper is NOT an article; it is in fact a very different document (just like a grant application is not a course paper or an article), and it has different conventions (and sometimes a different structure) as a result. Articles do not need long and windy rehearsals of existing literature on the topic; they benefit from jumping straight into the "so what?" and then backtracking to fill in not-especially-well-known contexts for readers who have been hooked by your compelling premise. They also benefit from a good amount of "signposting": reminders to readers throughout about where the argument is going, and how this particular moment in the paper connects to the larger whole. Finally, of course, there is the problem of the paper that tries to do too much: what I call the 2-in-I paper. These two exciting ideas obviously relate, but do they connect, right here, in this paper I've written? Do they really connect? How might I shift things structurally in order to make that connection clearer-both to myself and to my readers? (Structure, Joanne taught me, is 50\% 
content: without a supportive structure, the most brilliant ideas are lost. This is my favourite comment to leave on the vast majority of undergraduate essays.)

The advice and support Joanne offered me in relation to my $T \mathcal{F}$ debut-manqué not only resulted, ultimately, in my own first properly peer-reviewed publication, it also supported the development of my fledgling career as an editor. Many editing projects and journal gigs later, I now look back and realize that I have learned heaps about my own writing through the process of reading and editing others' work; I've also seen Joanne's advice, as I've paid it forward time and again, support countless students and colleagues in the evolution of their own writing. When I think about why I've chosen to edit so much over the course of my career so far, and about why I rarely say no when asked to read colleagues' work, I think about the profound satisfaction this teaching-learning process has brought me. I think too, and proudly, about the many outstanding pieces of research undertaken and laboured over by others that I've helped to bring to the page in sometimes small, and sometimes lesssmall, ways.

This issue of TRIC/RTAC celebrates the labour of mentorship, the enduring power of our pedagogies, in a host of different ways. We open with a landmark reflection on teaching across racial and ethnic borders by Colleen Kim Daniher. In "On Teaching Kim's Convenience in the Asian American Theatre and Performance Studies Classroom," Daniher uses her own experience as a postdoctoral fellow in the classroom at Brown University to reflect on the interwoven histories of Asian Canadian and Asian American activism, the "model minority myth," and North American Black-Asian relations; she then proposes an interdisciplinary and cross-border methodology for teaching Asian Canadian works in a transnational context, and offers a forceful call to action for the developing field of Asian Canadian theatre studies. (As a side note, I'm particularly proud to publish this article here, as Daniher was among the very first of my undergraduate students in drama at Western University, in 2005.)

Following Daniher's essay is Monique Hamel's "La question du "réel et son double " dans les créations théâtrales au secondaire," which explores how "the double," as the function at the heart of theatrical creation, impacts the creative explorations and learning processes of secondary school students. "How does the question of the double emerge from creative work, and how is it significant in the student's journey...?” asks Hamel, basing her research on three separate creative processes and on interviews charting the experiences of six participant-students who are now adults. While Daniher invites fresh thinking about how we structure and communicate complex difference in our classrooms, Hamel explores the ways in which living inside the most basic structures of difference occasioned by the theatre can assist students in life-long learning about both themselves and others.

Kelsey Jacobson picks up the thread of the "double" as well as that of the "real" from Hamel as she follows Rising Tide Theatre's "Trinity Pageant" around the outports of Newfoundland. In "Through the Fictive to the Real(ish): Affective Time and the Representation of 'Real Newfoundland' in Rising Tide Theatre's Trinity Pageant," Jacobson ranges across site-specific theatre, theories of performative time, and historical re-enactment practices as she asks what kind of "real Newfoundland" the Trinity Pageant chases, and why. A loving tribute to a community's shared oral history, as well as a rich critique of the ways in which performance cultures are routinely harnessed to economic survival in many postindustrial rural or semi-rural communities, Jacobson's article ultimately asks if the "real(ish)" 
of the pageant's semi-accurate, largely affective "real" Newfoundland isn't perhaps more real than not-especially if it is going to be the lifeline that allows communities like Trinity to survive in a globalized, neoliberalized, twenty-first-century Canada.

Jacobson is a senior $\mathrm{PhD}$ student at the University of Toronto, and her second contribution to this issue appears in "Accuracy and Ethics, Feelings and Failures: Youth Experimenting with Documentary Practices of Performing Reality" alongside fellow graduate student Scott Mealey and professor Kathleen Gallagher, on whose SSHRC-funded research both Jacobson and Mealey have worked. A model of scholarly mentorship as well as a compelling research conversation, this final article explores the use of documentary theatre and oral history practices in three different devising classrooms in Canada and Taiwan. Tracing young theatre makers' impulses to get their stories "right" on stage, Gallagher, Jacobson, and Mealey ask how an ethics of failure built into the processes of truth-telling on stage may support an ultimately more rigorous engagement with complex socio-political issues for young people.

Our issue concludes with an expanded Forum section, and features two more acts of radical pedagogy. In the first, Glen Nichols curates a conversation about the often-hidden powers of the liberal arts - and particularly of theatre studies - in Canadian universities, based on several years of shared in-person and online discussion at CATR conferences. Contributors Claire Carolan, Justin Bloom, Moira Day, Shelley Scott, and James McKinnon make, together, a powerful case for the value of theatre and performance pedagogy as a "mobile critical paradigm" (as Freeman and Gallagher put it in In Defence of Theatre, 2016); along the way they also offer some exceptional examples of pedagogical innovation from which we all, seasoned teachers and new, may learn. In the second Forum contributionwhich is also our online issue "leader"-Ric Knowles, Natalie Alvarez, and the team at Modern Times Theatre Company share an abridged version of the report based on their April 2017 "Post-Marginal" workshop and symposium. Asking how we might move beyond paying lip-service to the value of diversity on stage and get on with embedding diversity at the heart of our rehearsal, critical, directing, and viewing practices, this report (and the gallery of images and web links that accompany it online) will offer a fulsome and invaluable window onto a game-changing event for anyone who was not able to attend in person last year, as well as a useful refresher for those of us who were.

This is also the first issue of TRIC/RTAC that will exist primarily online. Going forward, subscribers to the journal will be asked to opt into print, if print is genuinely preferred. Readers print and digital will all, however, have the same rigorous engagement with Canadian theatre and performance scholarship to look forward to in TRIC/RTAC's future, along with new, web-only offerings that will be born-digital by the editorial resources we will be able to free up as we shift online. Thanks to this shift, I hope that a fresh generation of teachers and learners, writers and editors, will be able to continue tangling with $T R I C / R T A C$ well into our shared digital future. 